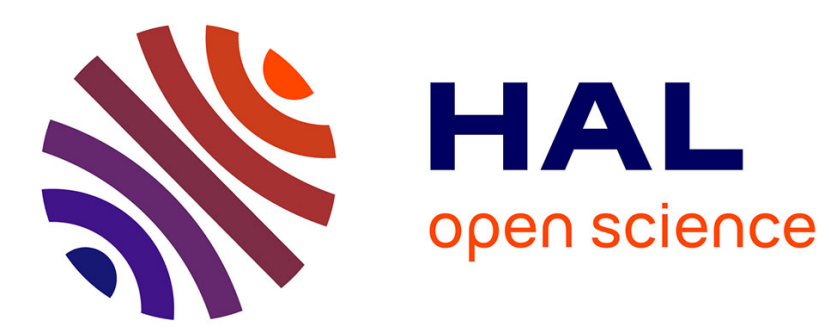

\title{
MAGNETIC PROPERTIES OF Ce (Zn1-xCux)2 SINGLE CRYSTALS
}

\author{
J. Voiron, P Morin, D. Gignoux, R. Aleonard
}

\section{To cite this version:}

J. Voiron, P Morin, D. Gignoux, R. Aleonard. MAGNETIC PROPERTIES OF Ce (Zn1xCux)2 SINGLE CRYSTALS. Journal de Physique Colloques, 1988, 49 (C8), pp.C8-419-C8-420. 10.1051/jphyscol:19888191 . jpa-00228346

\section{HAL Id: jpa-00228346 https://hal.science/jpa-00228346}

Submitted on 1 Jan 1988

HAL is a multi-disciplinary open access archive for the deposit and dissemination of scientific research documents, whether they are published or not. The documents may come from teaching and research institutions in France or abroad, or from public or private research centers.
L'archive ouverte pluridisciplinaire HAL, est destinée au dépôt et à la diffusion de documents scientifiques de niveau recherche, publiés ou non, émanant des établissements d'enseignement et de recherche français ou étrangers, des laboratoires publics ou privés. 


\title{
MAGNETIC PROPERTIES OF Ce $\left(\mathrm{Zn}_{1-x} \mathrm{Cu}_{x}\right)_{2}$ SINGLE CRYSTALS
}

\author{
J. Voiron, P. Morin, D. Gignoux and R. Aleonard \\ Laboratoire Louis Néel, C.N.R.S., 166X, 38042 Grenoble Cedex, France
}

Abstract. - We present magnetization measurements performed on $\mathrm{CeZn}_{2}$ and $\mathrm{Ce}\left(\mathrm{Zn}_{0.75} \mathrm{Cu}_{0.25}\right)$ single crystals along the $a, b$ and $c$ directions of the orthorhombic structure between $1.5 \mathrm{~K}$ and $300 \mathrm{~K}$. Evolution of magnetic properties in the $\mathrm{Ce}\left(\mathrm{Zn}_{1-x} \mathrm{Cu}_{\mathfrak{x}}\right)_{2}$ series is discussed considering crystalline electric field, magnetic interactions and Kondo effect.

$\mathrm{CeZn}_{2}$ and $\mathrm{CeCu}_{2}$ crystallize in the same or-

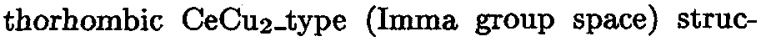
ture. Their magnetic properties are highly anisotropic but quite different. $\mathrm{CeZn}_{2}$ orders antiferromagnetically [1] around $7 \mathrm{~K}$ with the magnetic moments in the b-direction. It is characterized by Ising type behaviour in the ordered state: the magnetization curves, with the field applied along the $\mathbf{b}$ direction, exhibit three steps and because of the huge anisotropy, magnetizations along the $a$ and $c$ axes are very small [2]. On the other hand, $\mathrm{CeCu}_{2}$ orders antiferromagnetically at $3.5 \mathrm{~K}[3]$ and neutron diffraction experiments suggest a very long-range antiferromagnetic structure [4]. However the easy axis is in the a direction and a metamagnetic-like behaviour has been observed at $1.5 \mathrm{~K}$. Resistivity measurements $[1,3]$ have shown that Kondo effect is present in these two compounds. We have undertaken to study the evolution of the magnetic properties in the $\mathrm{Ce}\left(\mathrm{Zn}_{1-x} \mathrm{Cu}_{x}\right)_{2}$ series and we present magnetizations of $\mathrm{CeZn}_{2}$ and $\mathrm{Ce}\left(\mathrm{Zn}_{0.75} \mathrm{Cu}_{0.25}\right)_{2}$ single crystals measured along the $a, b$ and $c$ axes at various temperatures between $1.5 \mathrm{~K}$ and $300 \mathrm{~K}$.

Magnetization measurements in $\mathrm{CeZn}_{2}$ along $\mathrm{b}$ in increasing and decreasing fields are reported in figure 1. They show the existence of five different phases versus applied magnetic field. The critical fields are respectively $H_{\mathrm{cl}}=22.5 \mathrm{kOe}, H_{\mathrm{c} 2}=44 \mathrm{kOe}$ and $H_{\mathrm{c} 3}=72 \mathrm{kOe}$ in agreement with the results of reference [1]. However, an additional phase is observed between $H_{\mathrm{c} 2}^{\prime}=40 \mathrm{kOe}$ and $H_{\mathrm{c} 2}$ at $4.2 \mathrm{~K}$ but only in decreasing field at $1.5 \mathrm{~K}$ (Fig. 1) because of the large hysteresis. Effectively our measurements show the existence of a hysteresis for $H_{\mathrm{c} 1}(=1.7 \mathrm{kOe}$ at $1.5 \mathrm{~K})$ and $H_{\mathrm{c} 2}(4 \mathrm{kOe})$ but no hysteresis for $H_{\mathrm{c3}}$.

Magnetization curves of a single crystal of $\mathrm{Ce}\left(\mathrm{Zn}_{0.75} \mathrm{Cu}_{0.25}\right)_{2}$ performed along the three directions of the orthorhombic structure present a quite different behaviour (Fig. 1). The easy axis is the a direction as in $\mathrm{CeCu}_{2}$ and the values of the magnetization along the three axes appear to be similar to those of $\mathrm{CeCu}_{2}$. For example, the values of the magnetization measured at $4.2 \mathrm{~K}$ in a field of $60 \mathrm{kOe}$ are $1.09 \mu_{\mathrm{B}}$ and $1.19 \mu_{\mathrm{B}}$ for the a-axis, 0.60 and $0.72 \mu_{\mathrm{B}}$ for the $\mathbf{b}$-axis and 0.18 and $0.20 \mu_{\mathrm{B}}$ for the $\mathbf{c}-$

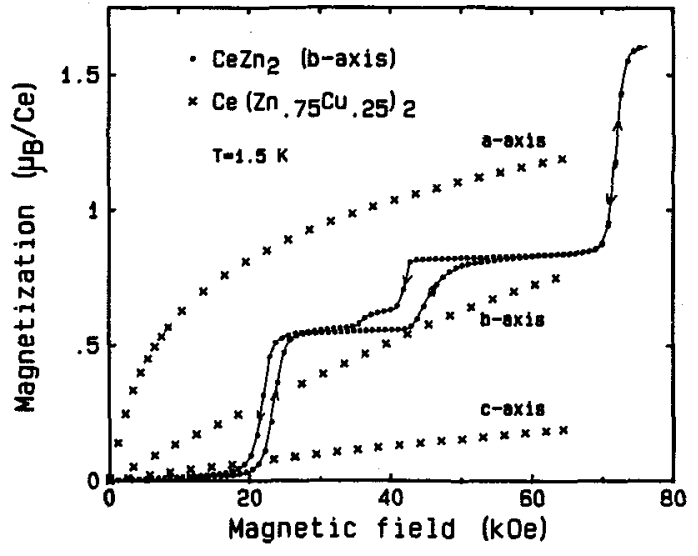

Fig. 1. - The magnetization of $\mathrm{CeZn}_{2}$ measured at $1.5 \mathrm{~K}$ along the $\mathrm{b}$-axis by increasing and decreasing field $(0)$ and the magnetization of $\mathrm{Ce}\left(\mathrm{Zn}_{0.75} \mathrm{Cu}_{0.25}\right)_{2}$ measured at $1.5 \mathrm{~K}$ along the $a, b$ and $c$ axes $(x)$.

axis for $\mathrm{Ce}\left(\mathrm{Zn}_{0.75} \mathrm{Cu}_{0.25}\right)_{2}$ and $\mathrm{CeCu}_{2}$, respectively [3]. However, the metamagnetic-like behaviour observed at $1.5 \mathrm{~K}$ in $\mathrm{CeCu}_{2}$ [4] has not been observed along any of the axes of $\mathrm{Ce}\left(\mathrm{Zn}_{0.75} \mathrm{Cu}_{0.25}\right)_{2}$.

Temperature dependences of the reciprocal susceptibility of $\mathrm{CeZn}_{2}$ and $\mathrm{Ce}\left(\mathrm{Zn}_{0.75} \mathrm{Cu}_{0.25}\right)_{2}$ measured along the $\mathbf{a}, \mathrm{b}$ and $\mathrm{c}$ axes are shown in figures 2 and 3 , respectively. The anisotropy of the susceptibility is very large in the whole range of temperatures, reflecting the orthorhombic crystal structure. The thermal variation of the low field susceptibility of $\mathrm{CeZn}_{2}$ along the $\mathbf{b}$-axis presents a maximum at $7 \mathrm{~K}$, which is the signature of the magnetic order. In contrast no such a maximum has been observed in the thermal dependence of the susceptibility of $\mathrm{Ce}\left(\mathrm{Zn}_{0.75} \mathrm{Cu}_{0.25}\right)_{2}$ compound. Contrary to $\mathrm{CeZn}_{2}$ and $\mathrm{CeCu}_{2}, \mathrm{Ce}\left(\mathrm{Zn}_{0.75} \mathrm{Cu}_{0.25}\right)_{2}$ does not order magnetically down to $1.5 \mathrm{~K}$. The paramagnetic Curie temperature $\theta_{\mathrm{p}}$ and the effective moments $\mu_{\text {eff }}$ have been deduced for each direction from the linear part of $\chi^{-1}(T)$ at high temperature and are listed in table I, with those of $\mathrm{CeCu}_{2}$ [5]. Properties of the $\mathrm{Ce}\left(\mathrm{Zn}_{0.75} \mathrm{Cu}_{0.25}\right)_{2}$ sample appear more similar to those of $\mathrm{CeCu}_{2}$ than those of $\mathrm{CeZn}_{2}$.

The paramagnetic susceptibilities of our two samples 


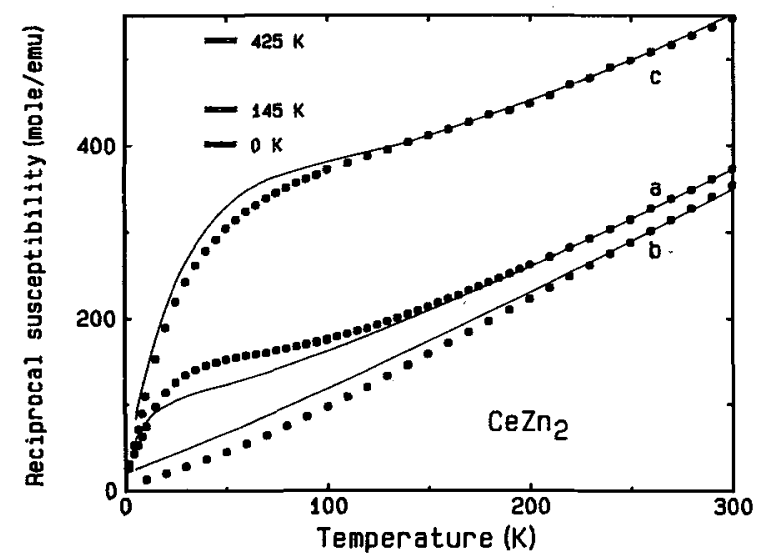

Fig. 2. - Temperature dependence of inverse magnetic susceptibility of $\mathrm{CeZn}_{2}$ along the $\mathrm{a}, \mathrm{b}$ and $\mathrm{c}$ axes and calculated curves.

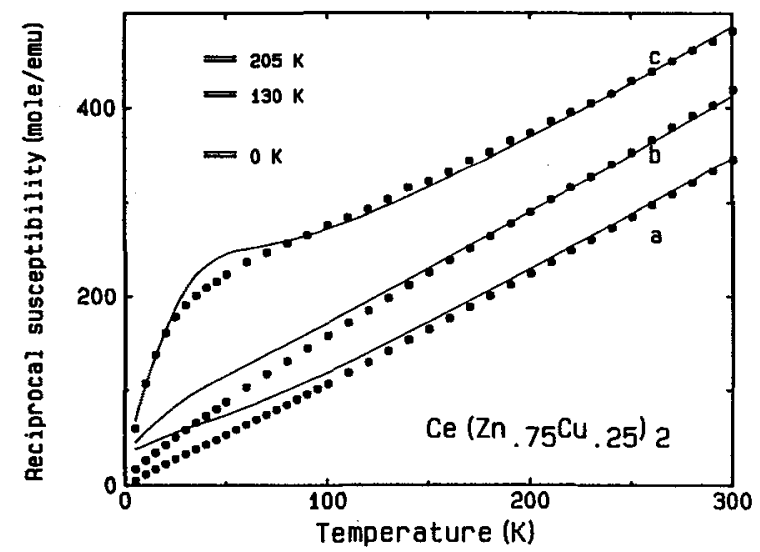

Fig. 3. - Temperature dependence of inverse magnetic susceptibility of $\mathrm{Ce}\left(\mathrm{Zn}_{0.75} \mathrm{Cu}_{0.25}\right)_{2}$ along the $\mathrm{a}, \mathrm{b}$ and $\mathrm{c}$ axes and calculated curves.

Table I. - The effective magnetic moment $\mu_{\mathrm{eff}}$ and the paramagnetic Curie temperatures $\theta_{\mathrm{p}}$ in $\mathrm{CeZ}_{2}$, $\mathrm{Ce}\left(\mathrm{Zn}_{0.75} \mathrm{Cu}_{0.25}\right)_{2}$ and $\mathrm{CeCu}_{2}$.

\begin{tabular}{|c|c|c|c|c|c|c|}
\cline { 2 - 7 } \multicolumn{1}{c|}{} & \multicolumn{2}{c|}{$\mathrm{CeZn}_{2}$} & \multicolumn{2}{c|}{$\operatorname{Ce}\left(\mathrm{Zn}_{0.75} \mathrm{Cu}_{0.25}\right)_{2}$} & $\mathrm{CeCu}_{2}$ (Ref. [5]) \\
\hline$H_{\mathrm{II}}$ & $\mu_{\mathrm{eff}}\left(\mu_{\mathrm{B}}\right)$ & $\theta_{\mathrm{P}}(\mathrm{K})$ & $\mu_{\mathrm{eff}}\left(\mu_{\mathrm{B}}\right)$ & $\theta_{\mathrm{P}}(\mathrm{K})$ & $\mu_{\text {eff }}\left(\mu_{\mathrm{B}}\right)$ & $\theta_{\mathrm{P}}(\mathrm{K})$ \\
\hline$a$ & 2.68 & -34 & 2.58 & +12.4 & 2.45 & +17 \\
$b$ & 2.47 & +30 & 2.49 & -23.5 & 2.36 & -25 \\
$c$ & 2.36 & -260 & 2.78 & -163 & 2.70 & -270 \\
\hline
\end{tabular}

are analysed using the usual expression

$$
\chi^{-1}(T)=\chi_{\mathrm{CF}}^{-1}(T)-\lambda
$$

$\chi_{\mathrm{CF}}(T)$ is the crystal field susceptibility obtained from the usual Hamiltonian in orthorhombic symmetry:

$$
\mathcal{H}_{\mathrm{CF}}=B_{2}^{0} O_{2}^{0}+B_{2}^{2} O_{2}^{2}+B_{4}^{0} O_{4}^{0}+B_{4}^{2} O_{4}^{2}+B_{4}^{4} O_{4}^{4}
$$

where $B_{l}^{m}$ and $O_{l}^{m}$ are crystal field parameters and Stevens operators respectively. $\lambda$ is the exchange term arising from magnetic interactions and takes also into account Kondo interactions.

The best agreement between calculated and measured curves is obtained for the following sets of parameters: $B_{2}^{0}=13.7$ and $8.3 \mathrm{~K}, B_{2}^{2}=0$ and $-9.1 \mathrm{~K}$, $B_{4}^{0}=-0.25$ and $-0.2, B_{4}^{2}=-3.8$ and $-1.1 \mathrm{~K}$, $B_{4}^{4}=-3.8$ and $0 \mathrm{~K}$ and $\lambda=-19$ and -31 mole/e.m.u. for $\mathrm{CeZn}_{2}$ and $\mathrm{Ce}\left(\mathrm{Zn}_{0.75} \mathrm{Cu}_{0.25}\right)_{2}$ respectively. The deduced crystal field level scheme is reported in figures 2 and 3. The high temperature susceptibility is well described and the shape of $\chi(T)$ curves at low temperatures is well reproduced but with a constant shift of all the curves (except for the a-axis of $\mathrm{CeZn}_{2}$ ). Uncertainties can proceed at high temperature (especially for the c-axis, the susceptibility of which is small) from the contribution of the matrix susceptibility which has not been subtracted. Differencies observed at low temperature can be attributed to a smaller Kondo temperature at low temperature than at high temperature, since the effective Kondo temperature is decreased in presence of the crystalline field [6] and depends on the degeneracy of the ground state level. A smaller Kondo temperature will drive a smaller $\lambda$ parameter in our fit and consequently a much better agreement (except for the a-axis of $\mathrm{CeZn}_{2}$ ).

Substitution of only $25 \%$ of $\mathrm{Zn}$ by $\mathrm{Cu}$ thus changes drastically the magnetic properties of $\mathrm{CeZn}_{2}$ and yields properties more similar to those of $\mathrm{CeCu}_{2}$. The stability of the peculiar metamagnetic properties of $\mathrm{CeZ}_{2}$ is probably limited to a narrow range of concentration. The Ising behaviour in $\mathrm{CeZ}_{2}$ should be due to a delicate balance between exchange interactions and Kondo effect in a compound with a large uniaxial anisotropy due to crystal field.

[1] Debray, D., Sougi, M. and Meriel, P., J. Chem. Phys. 56 (1972) 4325.

[2] Yamashita, M., Kurisu, M., Kadomatsu, H., Oguro, I. and Fujiwara, H., J. Phys. Soc. Jpn 56 (1987) 32.

[3] Onuki, Y., Machii, Y., Shimizu, Y., Komatsubara, T. and Fujita, T., J. Phys. Soc. Jpn 54 (1985) 3562.

[4] Gratz, E., Bauer, E., Barbara, B., Zemirli, S., Steglich, F., Bredl, C. D. and Lieke, W., J. Phys. F. 15 (1985) 1975.

[5] Takayanagi, S., Onuki, Y., Komatsubara, T., J. Phys. Soc. Jpn 55 (1986) 2384.

[6] Okiji, A., Kawakami, N., J. Magn. Magn. Mater. 54-57 (1986) 327. 